\title{
Student Experience of E-Learning Tools in HE: An Integrated Learning Framework
}

\author{
Aftab Dean \\ Andy Lima \\ Leeds Business School
}

\begin{abstract}
Over the last decade the adoption of a Virtual Learning Environment (VLE), at University, has become an accepted norm of support for student learning. However, despite the major investment in VLE's there is a major disparity between what universities are offering, on their online platforms, and how this material and activities are being utilised by students. This research provides empirical evidence of the passive use, both by tutors and students, of the VLE. The literature provides evidence of the inertia that still exists, within Higher Education (HE), among tutors, to fully embrace the spectrum of VLE engagement tools. The lack of transition, among many tutors, to utilise the VLE as a pedagogical engagement tool continues to impact the expectations of fee paying students in the UK, who no longer expect that a Socratic dialogue will suffice to catalyse their intellectual curiosity. Today's generation of students have been exposed to a plethora of technologies that facilitates the acquisition of instant information and often through a multitude of sensory (visual, audio) formats. Furthermore, with the growth of Massive Open Online Courses (MOOCS) that are freely available to students the expectations, of $\mathrm{HE}$ students, from universities is becoming more demanding. In light of this competitive virtual learning landscape the authors propose a learning framework. To enable universities to create a unique and effective learning experience, for their students, through prudent investment in VLE tools and a complimentary learning environments. Resulting in deeper learning and informed students prepared for seminars.
\end{abstract}

Keywords: Blackboard, VLE, pedagogy, e-Learning, Technology, higher education,

\section{Introduction}

Fully immersive effective learning opportunities do exist and are now starting to be exploited by some players in H.E. although these new technologies are still being embraced by a limited number of faculty and H.E institutions. However, the increasing level of competition coupled with market disruptions that are occurring in Higher Education (HE) (Staton, 2014) is resulting in universities to accelerate their adoption of new technologies to offer students the opportunity to engage with e-learning. The importance of this investment has become paramount in an era of where students, in England, are paying fees for their studies and many are having to finance their higher education through part time employment. Croxton (2014) has articulated a number of benefits of online learning that include flexibility in participation; ease of access and convenience. Consequently, a more flexible learning approach that allows students to balance their work and study commitments is needed. Furthermore, Redecker et al. (2011) advocates that access to Technology Enhanced Learning (TEL) platforms can be a major influence when choosing where to study for higher education, alongside traditional options such as employment prospects of graduating students. Hence, technology is becoming a major asset and competitive advantage for universities competing in an ever growing globally competitive market.

Evidence from research undertaken by Fieldman (2016), on HE student experience, affirms that good use of technology effectively enhances their learning experience. Although, when it comes to attracting and retaining students, in this day and age, there is no one-size fits all solution. Institutions appear to be struggling not necessarily with the changes but how fast they should adapt and which TEL system to adopt (Schedjbal, 2012). Some institutions have also struggled to fullyengage students or even to motivate them in the adoption of a VLE. Traditionally, adoption and inclusion of new technologies by faculty and academics have not been received so warmly, nevertheless, with the winds of changes and everyday new platforms being made available online, $\mathrm{HE}$ institutions must move fast to understand student's preferences 
and how they want to use technology in order to enable them to achieve their learning goals (Staton, 2014) in an evolving competitive online landscape.

\section{Online Competition}

Universities are facing increasing competition not only from their traditional market competitors but today from other industries who are investing in the online education market. A notable competitor is Laureate (http://www.laureate.net/OurNetwork/Europe/UnitedKingdom) who have partnered with universities to offer online courses. However, the major competition may arise from publishers such as Pearson, Cengage and McGraw-Hill who are actively pursuing market growth in the higher education sector. As they transform their textbooks into online module courses.

The traditional university education is being further disrupted by Massive Open Online Courses (MOOCS) that are sweeping the HE landscape. MOOCS offer universities the opportunity to engage a global audience at little or no cost to the participant. Key players in this market such as Coursera, Futurelearn, edX and Udacity have positioned themselves as serving a social good, offering higher education to an audience where access is limited (Agarwal, 2013). However, there is criticism that MOOCS have not been able to significantly improve the opportunities for socially disadvantaged communities in the developed countries (Bear, 2013; Sharma, 2013). Although, a surprising benefit of MOOCS has been identified by Longstaff (2017) who discovered that existing students, in HE, used MOOCS as it encouraged this group of students to try new things without the fear of failure. As the extrinsic threat of failure of a module can cause grade anxiety and result in a depreciated learning process that results in students under challenging their intellectual capabilities and affect their wellbeing (Conroy et al, 2008; Docan, 2006).

In relation to e-leaning activities Yang (2016) contends that among academic researchers there is a growing momentum that is moving away from traditional class-based or campus-based teaching paradigms towards the idea of ubiquitous learning spaces or learning ecosystems. These environments are able to provide an interoperable, pervasive, and seamless learning architecture that are intuitive and context relevant (Rizebos, 2016) to enhance the student experience. To achieve this universities need to appreciate the potential and challenges of Technology Enhanced Learning (TEL) that can be used as a single point of learning or in conjunction with traditional face-to-face learning methods. As Technology Enhanced learning affects what, how, where and when people learn (Davidson and Goldberg 2009).

\section{E-Learning}

Most academics and pedagogues agree that for an e-learning environment to exist instruction must be delivered on a digital device that is used with the intention to promote and support learning activities within a specific program or academic framework (Clark and Mayer, 2011). To facilitate e-learning Fee (2009) has identified three main elements that must interplay within an e-learning environment: 1) technology, 2) learning content and 3) learning design.

As academic time is expensive institutions might turn to technology not only to promote better engagement with students but reduce their labour costs (Schedjbal, 2012). Ubiquitous learning technologies must have the ability to not only facilitate highly dynamic, adaptable and engaging virtual learning environments but also to address individual needs of learners offering personalised experiences. It must offer opportunities to integrate into people's lives and allow them to adapt their training objectives, schedule and pace to individual needs and preferences (Redecker, 2011). Consequently, the successful adoption of e-learning will be significantly influenced by the integration of pedagogy with technology.

\section{Pedagogy and VLE}

Teaching and learning processes have been increasingly influenced by technological, instructional and pedagogical advances (Chou \& Tsai, 2002; Kavanoz, Yüksel \& Özcan, 2015). These developments will have greater influence in the future since the UK government decided to introduce a new metric to assess Universities through the Teaching Excellence Framework. Consequently, the current quality of teaching provision will face unexpected outcomes (Deloitte, 2015).

Technology is not only affecting what students will learn, but also how they will learn. These changes in technology and pedagogy have resulted in transformed habits of learning behaviour due to access to constant information and exposure to distractions (Persico \& Pozzi, 2015). This will require educators to evaluate how students are using the technology for 
learning. To ensure they design a participative, digitally-enabled and collaborative environment going beyond the individual educational institution (Linton and Schuchhard 2009).

The pedagogical-technological gap that exists, in many universities, is according to Naaji et al. (2015) attributed to:

- Rigid policies in formal education related to curricular systems and assessment practices

- Lack of investment in tutor training of VLE capabilities to explore, understand, evaluate and use best practices to engage students;

- Developed scenarios and best cases are still presented in a formal manner;

To help appreciate the technology advancements for e-learning tutors need to appreciate contemporary practices to utilise current technology to enrich the student e-learning experience. In their paper, Naaji et. al., (2015) provide a chronological overview of the technologies that have been adopted for learning (see Table 1).

Table 1 - Emerging technologies in Education as reported by the HPR 2008-2015

\begin{tabular}{|c|c|c|c|}
\hline HPR & One Year or Less & Two to Three Years & Four to Five Years \\
\hline 2008 & $\begin{array}{l}\text { - Grassroots Video } \\
\text { - Collaborations Webs }\end{array}$ & $\begin{array}{l}\text { - Mobile Broadband } \\
\text { - Data Mashups }\end{array}$ & $\begin{array}{l}\text { - Collective Intelligence } \\
\text { - Social OSs }\end{array}$ \\
\hline 2009 & $\begin{array}{l}\text { - Mobiles } \\
\text { - Cloud Computing }\end{array}$ & $\begin{array}{l}\text { - Geo Everything } \\
\text { - The Personal Web }\end{array}$ & $\begin{array}{l}\text { - Semantic Aware Apps } \\
\text { - Smart Objects }\end{array}$ \\
\hline 2010 & $\begin{array}{l}\text { - Mobile Computing } \\
\text { - Open Content }\end{array}$ & $\begin{array}{l}\text { - Electronic Books } \\
\text { - Simple Augmented Reality }\end{array}$ & $\begin{array}{l}\text { - Gesture-Based Computing } \\
\text { - Visual Data Analysis } \\
\end{array}$ \\
\hline 2011 & $\begin{array}{l}\text { - Electronic Books } \\
\text { - Mobiles }\end{array}$ & $\begin{array}{l}\text { - Augmented Reality } \\
\text { - Game-based Learning }\end{array}$ & $\begin{array}{l}\text { - Game-Based Learning } \\
\text { - Learning Analytics }\end{array}$ \\
\hline 2012 & $\begin{array}{l}\text { - Mobile Applications } \\
\text { - Tablet computing }\end{array}$ & $\begin{array}{l}\text { - Gesture-Based Computing } \\
\text { - Learning Analytics }\end{array}$ & $\begin{array}{l}\text { - Gesture-Based Computing } \\
\text { - Internet of Things }\end{array}$ \\
\hline 2013 & $\begin{array}{l}\text { - MOOCs } \\
\text { - Tablet Computing }\end{array}$ & $\begin{array}{l}\text { - Game \& Gamification } \\
\text { - Learning Analytics }\end{array}$ & $\begin{array}{l}\text { - 3D Printing } \\
\text { - Wearable Technology }\end{array}$ \\
\hline 2014 & $\begin{array}{l}\text { - Flipped Classroom } \\
\text { - Learning Analytics }\end{array}$ & $\begin{array}{l}\text { - 3D printing } \\
\text { - Games and Gamification }\end{array}$ & $\begin{array}{l}\text { - Quantified Self } \\
\text { - Virtual Assistants }\end{array}$ \\
\hline 2015 & $\begin{array}{l}\text { - Bring Your Own Device (BYWD) } \\
\text { - Flipped Classroom } \\
\text { - (Learning Analytics) } \\
\text { - (Mobile Apps) }\end{array}$ & $\begin{array}{l}\text { - Makerspaces } \\
\text { - Wearable Technology } \\
\text { - (Collaborative Environments) } \\
\text { - (Games \& Gamification) }\end{array}$ & $\begin{array}{l}\text { - Adaptive Learning Technologies } \\
\text { - The Internet of Things } \\
\text { - (Wireless Power) } \\
\text { - (Flexible Displays) }\end{array}$ \\
\hline
\end{tabular}

(Source: Naaji et. al. 2015).

There are many issues to consider when adopting Technology Enhanced Learning (TEL) platforms, for online or blended courses, the most important aspects are those related to student's adoption, motivation and learning development and the quality of the outcomes produced by combinations of these factors. Thus for universities to remain competitive Kregor et al (2012) argues that there is no longer a choice regarding implementing an e-learning strategy. While, the format and delivery of this e-learning strategy is still a contentious issue, there are many examples of Universities gradually moving to the full integration of technology into pedagogy through blended learning.

\section{Blended Learning}

Universities have made concerted investments in technology and many, in the UK, have adopted a 'blended learning' approach to deliver course content (Wade, 2012). Oliver and Trigwel (2005) and Bliuc et al (2007) advocate that the blended learning is a mix of traditional methods (face to face teaching) and online teaching. Research by Martinez-Caro and Campuzano-Bolarin (2011) revealed that satisfaction was significantly greater in blended learning courses than the traditional face to face courses. Even though there is evidence of a positive experience of blended learning research by Osgerby (2013) concluded that students still preferred face-to-face lectures. This is supported by Lily et al (2014) and Platt et al. (2014) who determined that students did not perceive online classes as being equivalent to a traditional delivered class due to the limited number of opportunities for interaction in comparison to a face to face course. 
While there is growing support for a blended learning approach that combines traditional lecture with online material results. The format and delivery of the blended format is still a nebulous subject. However, recent evidence of the flipped learning model is proving to be highly popular and effective in engaging student learning both through VLE and face to face contact.

\section{Flipped Learning}

The flipped classroom is emerging as one of the most recent popular technology-infused learning models. A flipped classroom approach requires students to undertake significant pre-class preparation that involves watching pre-recorded lecture videos and reviewing academic and practitioner material to enable traditional class time to be reserved for discussion and problem solving of the subject topic. It is said that learning is "flipped," "inverted," or "reversed" since it happens in a sequence directly opposed to the traditional way of delivering (Bergmann and Sams 2012).

Most adopters of the flipped learning model believe that by implementing these technological pre-classroom resources release tutors to do what they to best improving the overall quality of the classroom interaction and learning process (Lee et. al, 2017). Classroom time is solely devoted to "discovering and sharing ideas with one-to-one assistance, scaffolding, and inspiration, all made feasible by offloading content delivery onto the online lectures that are better at visual representations and self-pacing" (Lee et. al, 2017, p.428) .

Another important aspect that is stressed in flipped learning is 'peer instruction'. Harvard Professor Eric Mazur developed in 1991 a model of 'peer instruction' providing material for students to prepare and reflect on prior to his classes. The students would then use that in class time increasing deeper cognitive thinking through peer interaction and tutor support. Mazur called this "just in time teaching" (Crouch and Mazur 2001).

The effectiveness of the flipped learning model was investigated by Tune et al. (2013) who concluded that the flipped model appeared to have a strong positive effect on overall student performance. They concluded that the success of this approach is enhanced by the use of in-class quizzes and homework which contributed to greater student participation in classroom discussions and ultimately improved student performance. However, concerns have been raised about the level of commitment and knowledge required as well as the time needed to develop these methods. Bergmann (2011) addressed some areas of resistance, in his blog post, by highlighting a number of challenges of successfully implementing flipped learning, namely:

\section{Video lectures lead to less engaged students.}

\section{Classes will become too big to support engagement with students.}

\section{It's just bad lecture on video.}

\section{Students with limited access to technology are hurt}

The main challenges of flipped learning are centred on the lack of resources and time scarcity of tutors. Furthermore, for an effective flipped classroom course to take place tutors must ensure that students have prepared for in-class sessions prior to class and must be fully prepared for the new demands of interactivity in the classroom to enable peer-instruction and engagement (Long et al., 2017). What is becoming evident, for the successful implementation of VLE, is that significant resources and cultural inertia challenges still remain to be resolved to release the full potential of an e-learning environment.

\section{Challenges of E-learning}

Despite the growth in VLE systems at Universities there is limited evidence of the successful integration of these platforms into student learning. One primary reason could be attributed to the lack of direction and support offered tutors to develop e-learning material and online engagement activities. A further reason could be assigned to the lack of understanding of how students wants to engage in learning, which platforms and content should we be aiming to engage them with? Bringing together the right mix of collaborators, contents and services requires universities to appreciate students' physical context (where and when) learners find themselves into (time and space), what the learning resources and services are available for the learners, and who are the learning collaborators that match the learners' needs (Ogata, \& Yano, 2004; Zhang, Jin, \& Lin, 2005). 
Bee (2013) has raised concern over the lack of consistency between modules on virtual learning environments (VLEs). However, universities are reviewing their e-learning modules to identify how they can introduce templates that offer minimum standards for the use of the VLE (Reed, 2014).

While there is common agreement that as a minimum modules should provide contact details for module tutors and timely information about assessment requirements, lecture notes and reading lists. Research by Reed and Watmough (2015) discovered that staff, at a Russell Group University, differed considerably from their students as to what should be uploaded on an online course module. The key disagreements, from the staff, were:

Provision of past exam papers ( $46 \%$ difference);

Online submission of coursework ( $41 \%$ difference);

Provision of module specification ( $38 \%$ difference);

Opportunity for draft / formative feedback on work (34\% difference).

Other issues rising from the more traditional VLE systems is that some consider them inflexible and promoting just a oneway approach to learning. A number of academics (Crosslin, 2010; Kloos et al., 2011) have argued that HE institutions should be turning to platforms that can integrated and fully engage students on their learning journey. While a number of technological and cultural inertia issues have been highlighted. The catalyst to propelling the success of e-learning will be the symbiotic application of pedagogy and technology to augment the student experience in $\mathrm{HE}$.

This paper seeks to analyse the current use of technology as a way to enhance learning outcomes for students. Since new technologies are influencing not only student-tutor engagement but also challenging traditional campus-based teaching and learning what we identified here as physical spaces. Virtual learning environments, flipped classrooms and blended are now integral part of the lexicon in most Universities challenging other well-stablished virtual learning environments such as Blackboard and Moodle that are anecdotally perceived, by many tutors, as magnified repositories of material that lack the catalyst to enthuse and engage students. The identifications of the student concerns and solutions to address the successful adoption of an integrated e-learning environment with traditional pedagogical delivery was the main drive for this research.

\section{Methodology}

This research adopted a mixed method approach to capturing student views, in $\mathrm{HE}$, on their experience of using a popular Virtual Learning Environment (VLE), namely: Blackboard, used at many universities. The research aimed to minimise the limitations of adopting a qualitative or quantitative approach to data collection by pursuing a sequential mixed method approach that would permit a deeper understanding of the student experiences of using a university VLE system. To enable the authors to put forward pragmatic solutions to address the current limitations of application of course modules that are available on VLE systems with varied degrees of success.

The initial phase involved inviting undergraduate students to five small focus group discussions to identify key themes of experience of using the Blackboard system. The discussion focused on why they used Blackboard and how it could be improved. The focus group discussions revealed a number of key themes that were translated into open ended questions and administered to 200 students in phase 2 of the methodology. After the responses were collected and reviewed from each respondent an acceptable 121 responses were analysed to identify key themes identified from each open-ended question.

Phase 3 of the data collection resulted in the design of an ordinal questionnaire based on the key responses identified in phase 2 that asked respondents to rate their experience, of using Blackboard, and suggestions for improvement. The questionnaire was administered at a Post-92 University in a major city in the North of England. The survey resulted in a total of 266 acceptable responses from students who identified themselves as being permanently resident in the UK. While it would have been preferable to include the views of international students the sample response rate was too small, for this group, and so it was decided to exclude this category and concentrate on the views of UK students.

\section{Findings}


The open ended questionnaire survey revealed a number of insights into how the current VLE system could be improved (see Tables 2 and 3 ). The findings centred on five core issues, namely: 1) more information on the module and tutor being available; 2) Better user interface to be adopted to find information; 3) More feedback and discussion forums on assessment; 4) Uploading of various multimedia (videos and audio of lectures); 5) Links to other external sources (e.g. online databases, external resources).

Table 2: How could Blackboard be improved?

\begin{tabular}{|l|l|}
\hline Reduce number of times system is unavailable. & 25 \\
\hline Information on lecture cancellations & 16 \\
\hline More help and information on assignment & 15 \\
\hline Better design and layout of uploaded information & 13 \\
\hline Easier user interface & 10 \\
\hline All module links available & 8 \\
\hline Forums for students to engage in discussions & 6 \\
\hline Lecture slides to be uploaded & 4 \\
\hline Tutor details to be available & 4 \\
\hline
\end{tabular}

Table 3: What would encourage you to use Blackboard more?

\begin{tabular}{|l|l|}
\hline All module information available & 19 \\
\hline More feedback & 15 \\
\hline Video/audio Lectures & 12 \\
\hline Wouldn't want to learn just by e-learning & 12 \\
\hline Clearer layout & 11 \\
\hline Links to journals & 11 \\
\hline Better Access (more computers on campus) & 10 \\
\hline Revision questions/Seminar questions & 6 \\
\hline All lecture slides available & 5 \\
\hline Forums & 5 \\
\hline More business resources & 4 \\
\hline More Information on Exam dates & 3 \\
\hline Assignment Help & 2 \\
\hline
\end{tabular}

\section{Survey Results}

The administered questionnaire resulted in 266 responses from UK students being accepted for analysis. This comprised of an almost equal number of respondents from both Genders (48.1\% Male and $51.5 \%$ Female). The average age of the students was 20 (range 18 to 25) who spent an average of 4 hours a week on the university Blackboard VLE system.

The majority of students accessed the VLE system either in the afternoon or in the evening (see Figure 1).

Figure 1: Time Periods VLE accessed 


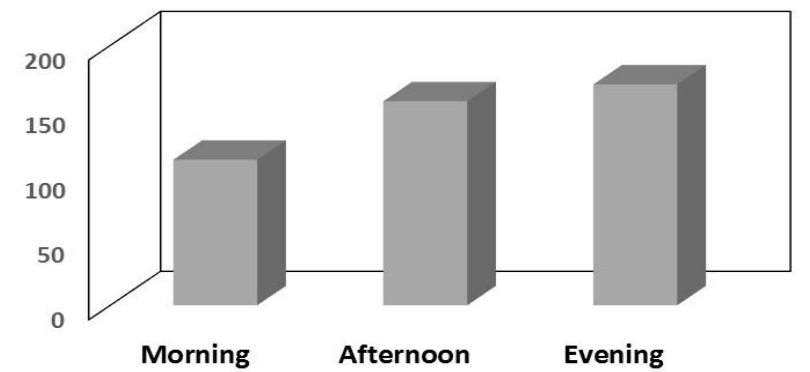

The questionnaire asked respondents to rate 22 options (see Table 4) on how the current VLE system could be improved. To ensure that the 22 options captured the array of experiences and suggestions an open ended question was included that asked students to provide further suggestions on how the VLE system could be improved. The open ended results complimented the 22 options and included responses that were categorised into the following themes:

More Discussion forums;

More help for assignment / revision sessions;

Examples of previous work / worked examples;

Weekly quizzes;

Multimedia upload: Podcasts / Videos;

Video conferencing / online discussions;

Improved navigation to location information;

Notification of class cancellation;

The open ended findings provided evidence that the VLE tools can complement the student experience by not only addressing the learning requirements for a module but also ensure that the module is effective in communicating with students any administrative changes.

To undertake advanced statistical analysis, of the survey data, initially the internal reliability of the 22 options was computed and the findings revealed a very high Cronbach's Alpha of .956. Subsequently, correlation analysis revealed moderate (.2) to strong (.8) correlations between the various options on improving the VLE system. As multicolinearity (i.e. the correlations between the 22 options were not high enough to unduly influence the results) was not an issue the data needed to be screened for normality to apply factor analysis.

\section{Test of Normality}

Before any analysis was undertaken, the data file was screened for missing data and all missing responses were deleted from the data file; additionally, measures to determine the normality of the data were undertaken. This required ensuring that Skewness was less than $+/-3$ and Kurtosis was less than $+/-10$. Both conditions were met (see Table 4), thus, the data was appropriate for multivariate analysis.

Table 4: Test of Skewness and Kurtosis 


\begin{tabular}{|c|c|c|c|c|c|}
\hline & & $\mathbf{N}$ & Mean & Skewness & Kurtosis \\
\hline 1 & Lecture and seminar notes & 266 & 5.65 & -0.774 & -0.041 \\
\hline 2 & additional notes and case studies & 266 & 5.64 & -0.624 & -0.456 \\
\hline 3 & past exam papers & 266 & 5.64 & -0.882 & 0.372 \\
\hline 4 & answers to past exams papers & 266 & 5.6 & -0.818 & 0.122 \\
\hline 5 & Exam and assignment results & 266 & 5.72 & -0.877 & 0.111 \\
\hline 6 & Assignment criteria & 266 & 5.72 & -0.788 & -0.144 \\
\hline 7 & Examples of good assignments & 266 & 5.61 & -0.79 & 0.031 \\
\hline 8 & List of academic sources that are useful & 266 & 5.63 & -0.775 & -0.021 \\
\hline 9 & Assignment feedback & 266 & 5.66 & -0.787 & -0.066 \\
\hline 10 & Calendar of module events (presentations) & 266 & 5.59 & -0.806 & 0.391 \\
\hline 11 & More module information & 266 & 5.41 & -0.293 & -0.887 \\
\hline 12 & Audio recordings of lectures & 266 & 5.05 & -0.491 & -0.483 \\
\hline 13 & Video recordings of lectures & 266 & 4.95 & -0.511 & -0.533 \\
\hline 14 & Lectures should host regular online discussions & 266 & 4.93 & -0.435 & -0.422 \\
\hline 15 & Lectures should clearly highlight their availability & 266 & 5.47 & -0.404 & -0.659 \\
\hline 16 & Online quizzes to help students learn the subject & 266 & 4.86 & -0.392 & -0.387 \\
\hline 17 & Links to useful websites & 266 & 5.08 & -0.303 & -0.681 \\
\hline 18 & Students should be given opportunity to write blogs & 266 & 4.64 & -0.137 & -0.641 \\
\hline 19 & Online learning should be personalised & 266 & 4.83 & -0.168 & -0.68 \\
\hline 20 & Students should be allowed to vote on academic issues & 266 & 4.85 & -0.227 & -0.811 \\
\hline 21 & $\begin{array}{l}\text { There should be clear instructions on how to navigate } \\
\text { online system }\end{array}$ & 266 & 4.83 & -0.198 & -0.832 \\
\hline 22 & There should be a link to UNI admin & 266 & 4.89 & -0.301 & -0.581 \\
\hline
\end{tabular}

\section{Test of Suitability of Data for Factor Analysis}

To confirm the appropriateness of factor analysis a series of statistical assumptions were reviewed. The Bartlett's test of sphericity (BTS $=5674.81, p<0.0)$, the Kaiser-Meyor Olkin measure of sampling adequacy $(\mathrm{KMO}=0.935)$ all indicated that the data was appropriate for conducting factor analysis for Oblique Rotation (Direct Oblim)

\section{Variance Explained by Factor Analysis}

Factor analysis using Oblique rotation (Direct Oblim) was employed as the correlation results revealed that the 22 items were correlated with each other. The factor analysis revealed THREE factors (see Table 6). The factor solutions further revealed a cumulative explained variance level of $74.01 \%$ (see Table 5) confirming the high level of agreement from the sample respondents.

Table 5: Factor groups identified and Variance Explained

\begin{tabular}{|c|c|c|c|}
\hline \multirow[b]{2}{*}{ Component } & \multicolumn{3}{|c|}{ Initial Eigenvalues } \\
\hline & Total & $\%$ of Variance & Cumulative \% \\
\hline 1 & 11.819 & 53.722 & 53.722 \\
\hline 2 & 2.888 & 13.126 & 66.848 \\
\hline 3 & 1.576 & 7.166 & 74.014 \\
\hline
\end{tabular}

\section{Exploratory Factor Analysis: Factor Loading (Oblique)}

The exploratory factor analysis (Oblique) revealed three factors (labelled: 1.Supplimentary Course Material; 2) Online Engagement Activities; 3) Multimedia Resources) (see Table 6). The factor loadings in each latent group revealed a high factor loading of greater than 0.5 . The factor groups compliment the findings in the literature in relation to activities to engage students and offer a more multimedia experience through the provision of video material.

Table 6: Three Factor identified 


\begin{tabular}{|c|c|c|c|}
\hline \multicolumn{4}{|l|}{ Pattern Matrix ${ }^{a}$} \\
\hline & \multicolumn{3}{|c|}{ Component } \\
\hline & 1 & 2 & 3 \\
\hline additional notes and case studies & 0.931 & & \\
\hline Exam and assignment results & 0.928 & & \\
\hline Lecture and seminar notes & 0.927 & & \\
\hline Assignment criteria & 0.898 & & \\
\hline past exam papers & 0.871 & & \\
\hline answers to past exams papers & 0.858 & & \\
\hline Examples of good assignments & 0.813 & & \\
\hline Assignment feedback & 0.805 & & \\
\hline List of academic sources that are useful & 0.723 & & \\
\hline Calendar of module events (presentations) & 0.714 & & \\
\hline Lectures should clearly highlight their availability & 0.584 & & \\
\hline More module information & 0.503 & & \\
\hline $\begin{array}{l}\text { There should be clear instructions on how to navigate online } \\
\text { system }\end{array}$ & & 0.906 & \\
\hline Students should be allowed to vote on academic issues & & 0.878 & \\
\hline Online learning should be personalised & & 0.855 & \\
\hline There should be a link to UNI admin & & 0.846 & \\
\hline Students should be given opportunity to write blogs & & 0.800 & \\
\hline Links to us eful websites & & 0.767 & \\
\hline Online quizzes to help students learn the subject & & 0.671 & \\
\hline Video recordings of lectures & & & 0.899 \\
\hline Audio recordings of lectures & & & 0.869 \\
\hline Lectures should host regular online discussions & & & 0.755 \\
\hline
\end{tabular}

\section{Discussion}

This paper raises questions over the educational impact of the use of passive traditional virtual learning environment (VLE) environments such as Blackboard to engage students in context aware ubiquitous learning. The findings of this research provide insights into the three key areas that students would like to see improved on the current usage of module, available on Blackboard, that involve tutors investing in:

1) Supplementary Course Material;

2) Online Engagement Activities;

3) Multimedia Resources

The contemporary flipped learning model is providing good evidence of the positive impact on student performance (Tune et al., 2014). However, evidence from this research points to much investment and effort that is required to meet student expectations of e-learning systems. Especially, as highlighted in the literature, there are a plethora of online tools and platforms (mostly available free such as Coursera, Futurelearn) that offer students a much richer and deeper online learning experience. Consequently, this research proposes a new learning framework that incorporate traditional pedagogy delivery with e-learning and self-study (see Figure 2) to enrich the student experience. 


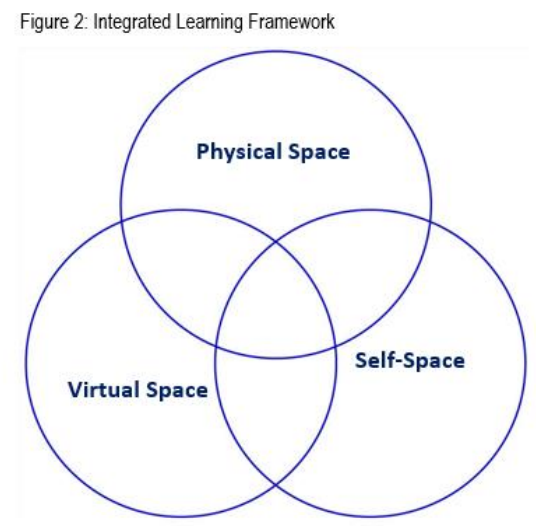

In terms of physical space this paper consider all the resources students and peers have at their disposal within the university campus such as lectures/seminars, labs, libraries, academic support, feedback, tutor time, etc. By virtual space we mean all the online platform that can be offered to students during the time of their learning program either via VLE or any other external virtual tool or third party app. We argue that the self-space points to what goes on within the student's own world and their minds, their own motivations, their skills and capabilities, their ability to absorb and capture key concepts and learning, etc. and how the external and virtual world are affecting their cognitive, emotive and neurologic capabilities.

The concept of the three spaces proposes that learning takes place not only in the realm of physical and virtual interaction but on the self and inner realm of student's own predisposition, cognitive capabilities, motivations, neuro-biology and psychology (feelings and emotions). This holistic overview of student learning offers universities an opportunity to be creative in the use of technology to engage and enhance the student learning journey in Higher Education.

\section{Recommendations}

As we enter a world of the Internet of Things (IOT) in which a multitude of devises will be connected to the internet that includes wearable technology. This will create new opportunities for Universities to develop material to engage their target audience. In which learning can take place anytime, anyplace and on almost any connected device. Based on the current findings the authors propose a number of recommendations to help universities attain an effective and impactful e-learning system for students, these include:

Development of a coherent vision and strategy for a VLE to enhance the student learning experience;

Agreement and articulation of the minimum expectations from any module that is offered on the VLE system;

Dedicated investment in training tutors to become familiar with the online learning systems and their range of tools to engage students;

Facilitating collaboration between tutors and media / multimedia designers to design visual content that captures the attention of users;

Utilising metric to capture the student engagement with the e-learning modules;

Development of pedagogical activities that capitalises on the capabilities of technology to engage and empower student learning independently.

\section{Referencing:}

[1] Agarwal, A. (2013). "Online Universities: It's Time for Teachers to Join the Revolution". The Guardian. http://www.guardian.co.uk/education/2013/jun/15/university-education-online-mooc [Accessed 18 Jun. 2013]

[2] Baker, J. W. (2000). "The classroom flipped: Using web course management tools to become the guide on the side". Paper presented at the 11th International Conference on College Teaching and Learning, Jacksonville, FL. 
[3] Bandura, A. (2004). "Health promotion by social cognitive means". Health Education \& Behaviour, 31(2), pp.143164.

[4] Bear, C. (2013). "Is Online Education Widening the Digital Divide?" Mind Shift. http://blogs.kged.org/mindshift/2013/08/is-online-education-widening-the-digital-divide/ [Accessed 20 Aug. 2013]

[5] Bergmann, J. (2011). "The Flipped Class Revisited". [Blog] The Flipped Class Blog. Available at: http://blendedclassroom.blogspot.co.uk/2011/12/flipped-class-revisited.html [Accessed 3 Sep. 2017]

[6] Bergmann, J., \& Sams, A. (2012). Flip your classroom. Eugene, OR: International Society for Technology in Education.

[7] Bland, L. (2006). "Applying flip/inverted classroom model in electrical engineering to establish life-long learning". Paper presented at 113th ASEE Annual Conference \& Exposition, Chicago, IL.

[8] Bliuc, A.-M., Goodyear, P. and Ellis, R.A. (2007). "Research focus and methodological choices in studies into students' experiences of blended learning in higher education". The internet and Higher Education, Vol. 10 No.4, pp.231-244

[9] Bousquet, M., Carmody, T., Grafton, A. T., Hermanowicz, J. C., Hu-DeHart, E., Stearns, P. N., \& Trower, C. A. (2009). "The faculty of the future: Leaner, meaner, more innovative, less secure". The Chronicle of Higher Education. Avaiable at: http://chronicle.com/article/The-Faculty-of-the-Future-/47017 [Accessed 30 Jul. 2017]

[10] C. Delgado Kloos et al. (2011). "Towards Responsive Open Learning Environments: The ROLE Interoperability Framework". (Eds.): EC-TEL 2011, LNCS 6964, pp.125-138

[11] Chou, C., \& Tsai, C. C. (2002). "Developing web-based curricula: Issues and challenges". Journal of Curriculum Studies, 34(6), pp.623-636

[12] Chyr, W.-L., Shen, P.-D., Chiang, Y.-C., Lin, J.-B., \& Tsia, C.-W. (2017). "Exploring the Effects of Online Academic Help-Seeking and Flipped Learning on Improving Students' Learning". Educational Technology \& Society. 20 (3), pp.11-23.

[13] Clark, R.C. and Mayer, R.E. (2011). "e-Learning and the Science of Instruction: Proven Guidelines for Consumers and Designers of Multimedia Learning". 3rd ed., San Francisco, USA: John Wiley \& Sons.

[14] Conroy, D. E., M. P. Kaye, and A. M. Fifer (2007). "Cognitive Links between Fear of Failure and Perfectionism". Journal of Rational-Emotive \& Cognitive-Behaviour Therapy. 25(4), pp.237-253

[15] Crosslin, M. (2010). "Social Learning Environment Manifesto". Available at: http://www.edugeekjournal.com/2010/03/18/social-learning-environment-manifesto/ [Accessed 30 Jul. 2017]

[16] Crouch C. H. and Mazur E. (2001). "Peer Instruction: Ten years of experience and results". Am. J. Phys., Vol. 69, No. 9, Sep.

[17] Croxton, R.A. (2014). "The role of interactivity in student satisfaction and persistence in online learning". MERLOT Journal of Online Learning and Teaching, 10(2), pp.314-325

[18] Davidson, C. N., \& Goldberg, D. T. (2009). "The Future of Learning Institutions in a Digital Age". John D. and Catherine T MacArthur Foundation Reports on Digital Media and Learning. MIT, Boston.

[19] Deloitte (2015). "Making the Grade 2015: The Key Issues Facing the UK Higher Education Sector". Deloitte UK.

[20] Docan, T. (2006), "Positive and Negative Incentives in the Classroom: An Analysis of Grading Systems and Student Motivation". Journal of Scholarship of Teaching and Learning 6(2), pp.21-40

[21] Fee, K. (2009). "Delivering E-Learning: A complete strategy for design, application and assessment". London, United Kingdom: Kogan Page, p.14.

[22] Feldman, P. (2016). "Higher education leaders share challenges of the sector". JISC. Available at: https://www.jisc.ac.uk/blog/higher-education-leaders-share-challenges-of-the-sector-27-jun-2016 [Accessed 29 Jul. 2017]

[23] Foertsch, J., Moses, G., Strikwerda, J., \& Litzkow, M. (2002). "Reversing the lecture/homework paradigm using e-Teach web-based streaming video software". Journal of Engineering Education, 91(3), pp.267-274.

[24] Grove, J. (2015). "7 key challenges for UK higher education". Times Higher Education. Available at: https://www.timeshighereducation.com/features/7-key-challenges-uk-higher-education [Accessed: 29 Jul 2017]

[25] Hao Y. (2016). "Exploring undergraduates' perspectives and flipped learning readiness in their flipped classrooms". Computers in Human Behaviour 59:82, pp.92

[26] Hwang, G.-J., Tsai, C.-C., \& Yang, S. J. H. (2008). "Criteria, Strategies and Research Issues of Context-Aware Ubiquitous Learning". Educational Technology \& Society, 11 (2), 81-91. 
[27] JISC (2016). The JISC higher education leadership barometer 2016: snapshot of findings. JISC. Available at: https://repository.jisc.ac.uk/6443/1/JD0117_LEADERSHIP_SURVEY_MAY2016_HE_v5.pdf [Accessed: 29 Jul 2017]

[28] Johnson, L., Adams Becker, S., Estrada, V. and Freeman, A. (2014). NMC Horizon Report: 2014 Higher Education Edition. Austin, Texas: The New Media Consortium.

[29] Kavanoz, D., Yüksel, H. G., \& Özcan, E. (2015). "Pre-service teachers' self-efficacy perceptions on web pedagogical content knowledge". Computers \& Education, 85, pp.94-101

[30] Khan S. (March, 2011). "Let's Use video to Reinvent Education" [Video file]. Available at: https://www.ted.com/talks/salman khan let s use video to reinvent education\#t-384389 [Accessed $01 \mathrm{Sep}$ 2017]

[31] Kregor G., Breslin M. and Fountain W. (2012), "Experience and beliefs of technology users at an Australian university: Keys to maximising e-learning potential". Australasian Journal of Educational Technology 28(8), pp.1382-1404

[32] Kurshan B. (2017). "What You Should Know Before Flipping for Flipped Learning". Available at: https://Www.Forbes.Com/Sites/Barbarakurshan/2017/04/26/What-You-Should-Know-Before-Flipping-ForFlipped-Learning/\#7b11ced023cc [Accessed 01 Sep 2017]

[33] Lee J., Lim C., Kim H. (2017). "Development of an instructional design model for flipped learning in Higher Education". Education Tech Research Dev (2017) 65, pp.427-453

[34] Lily W., Tatnall A. and Burgess S. (2014), "A framework for investigating blended learning effectiveness," Education + Training, Vol. 56, Issue: 2/3, pp.233-251

[35] Linton P., \& Schuchhard P. (2009). "The Digital World in 2025". Indicators for European Action: European Internet Foundation (EIF).

[36] Long T., Cummins J., Waugh M. (2017). "Use of the flipped classroom instructional model in higher education: instructors' perspectives". J Computer High Education 29, pp.179-200

[37] Longstaff E. (2017). "How MOOCS can empower learners: a compassion of provider goals and user experiences," Journal of Further and Higher Education, 41:3, pp. 314-327

[38] Makice K. (2012). "Flipping The Classroom Requires More Than Video". Available at: $<$ https://www.wired.com/2012/04/flipping-the-classroom/ [Accessed on 01 Sep 2017]

[39] Martinez-Caro, E. and Cmpuzano-Bolarin, F. (2011), "Factors affecting students' satisfaction in engineering disciplines: traditional vs blended approaches." European Journal of Engineering Education, 36:5, pp.473-483

[40] Mclnnerney, J. M., \& Roberts, T. S. (2004). "Online learning: Social interaction and the creation of a sense of community". Educational Technology \& Society, 7(3), pp.73-81.

[41] Naaji A., Mustea A., Holotescu C., Herman C (2015). "How to Mix the Ingredients for a Blended Course Recipe". BRAIN. Broad Research in Artificial Intelligence and Neuroscience, Vol. 6, Issues 1-2, September 2015.

[42] Noble, David F (2002). "Technology and the commodification of higher education". Monthly Review; New York53.10 (Mar 2002), pp.26-40

[43] Ogata, H., \& Yano, Y. (2004). "Context-Aware Support for Computer-Supported Ubiquitous Learning". Paper presented at the 2nd IEEE International Workshop on Wireless and Mobile Technologies in Education, March 23-25, 2004, JhongLi, Taiwan.

[44] Oliver, M and Trigwell, K., (2005). Can 'Blended Learning' be redeemed? E-learning, 2 (1), pp.17-26

[45] Osegerby, J. (2013), 'Students' perceptions of the introduction of a blended learning environment: an exploratory case study", Accounting Education, Vol 22 No. 1, pp.85-99

[46] Park, S. Y. (2009). "An Analysis of the Technology Acceptance Model in Understanding University Students' Behavioral Intention to Use e-Learning". Educational Technology \& Society, 12 (3), pp.150-162

[47] Persico, D., \& Pozzi, F. (2015). "Informing learning design with learning analytics to improve teacher inquiry". British Journal of Educational Technology, 46(2), pp.230-248

[48] Redecker C., Leis M., Leendertse M., Punie Y., Gijsbers G., Kirschner P., Stoyanov S. and Hoogveld B. (2011). "The Future of Learning: Preparing for Change". Institute for Prospective Technological Studies. JRC-European Union.

[49] Reed, P. (2014), Sector-wide subscription to VLE minimum standards. The Reed Diaries. Available at: http://thereeddiaries.blogspot.co.uk/2014/03/sector-wide-subscription-to-vle-minimum.html [Accessed 21 March 2014] 
[50] Reed, P. and Watmough, S. (2015). "Hygience factors: Using VLE mimimum standards to avoid student dissatisfaction," E-Learning and Digital Media, Vol 12(1), pp.68-89

[51] Schedjbal, D. (2012). "In Search of a New Paradigm for Higher Education". Innovative High Education, 37, pp.373-386

[52] Sharma, G. (2013), "A MOOC Delusion: Why Visions to Educate the World Are Absurd". The Chronicle of Higher Education. $\quad$ http://chronocle.com/blogs/worldwise/a-mooc-delusion-why-visions-to-educate-the-world-areabsurd/32599 [Accessed 17 July 2013]

[53] Staton, M (2014). "Universities Are Missing Out on an Explosive Growth Sector: Their Own". Harvard Business Review. Available at: https://hbr.org/2014/06/universities-are-missing-out-on-an-explosive-growth-sector-theirown [Accessed $06 \mathrm{Jul}$ 2017]

[54] Strayer, J. (2012). "How learning in an inverted classroom influences cooperation, innovation and task orientation". Learning Environments Research, 15(2), pp.171-193

[55] Tsai, C. W. (2013a). "An Effective online teaching method: The Combination of collaborative learning with initiation and self-regulation learning with feedback". Behaviour \& Information Technology, 32(7), pp.712-723

[56] Tsai, C. W., Shen, P. D., \& Lu, Y. J. (2015). "The Effects of problem-based learning with flipped classroom on elementary students' computing skills: A Case study of the production of E-books". Available at: https://pdfs.semanticscholar.org/f500/6cd90c1223d33d0e4160d75e505ca4743d41.pdf [Accessed 6 Sep 2017]

[57] Tune, J.D.; Sturek, M. and Basile, D.P. (2013). "Flipped classroom model improves graduate student performance in cardiovascular, respiratory and renal physiology." The American Physiological Journal, Vol.37, pp.316-320

[58] Wade, R. (2012), "Pedagogy, places and people". Journal of teacher Education for Sustainability, Vol. 14 No. 2, pp.147-167

[59] Yang, S. J. H. (2006). "Context Aware Ubiquitous Learning Environments for Peer-to-Peer Collaborative Learning". Educational Technology \& Society, 9 (1), 188-201

[60] Zhang, G., Jin, Q., \& Lin, M. (2005). "A Framework of Social Interaction Support for Ubiquitous Learning”. Paper presented at the 19th International Conference of Advanced Information Networking and Applications, March 28-30, 2005, Tamkang University, Taiwan.

[61] Zhu, Z. T., Yu, M. H., \& Riezebos, P. (2016). "A research framework of smart education". Smart Learning Environments, 3(1), 4. 